\title{
Field observations and lessons learnt from the 2018 landslide disasters in Idukki District, Kerala, India
}

\author{
Debi Prasanna Kanungo ${ }^{1,3}$, Ravinder Singh ${ }^{2}$ and Rajesh Kumar Dash ${ }^{3, *}$ \\ ${ }^{1}$ CSIR-Central Building Research Institute, Roorkee 247 667, India \\ ${ }^{2}$ National Disaster Management Authority, New Delhi 110 029, India \\ ${ }^{3}$ Academy of Scientific and Innovative Research, Ghaziabad 201002 , India
}

The landslide events, that occurred in August 2018 in the Idukki district Kerala, India were surveyed during 12-14 September 2018. Many landslides were studied through field observations to decipher their mechanism and mitigation measures have been recommended. Possible causative factors responsible for these slope failures have been discussed. This event was the most devastating disaster that affected millions of people and the second such event after the Kedarnath tragedy (2013) during this decade. The primary causes responsible for initiation of these landslides were unexpected intense rainfall, unplanned development and urbanization. This study on field observationbased interpretations will help academicians, researchers and field engineers to plan future initiatives for reconstruction planning and implementation in line with future disaster risk reduction.

Keywords: Causative factors, field observations, landslide disasters, mitigation measures, risk reduction.

THE southwest (SW) monsoon commenced in the last week of May 2018 and the 'exceptionally high rainfall' evoked a number of landslide incidences in the central and northern parts of Kerala, India. According to Indian Meteorological Department (IMD) data, June 2018 received 15\% 'excess' rainfall whereas during July 2018 the figure was $18 \%$ 'excess'. These were despite the $37 \%$ excess pre-monsoon rainfall from 1 March to 31 May 2018. The first spell of 'exceptionally high' rainfall was received from 8 to 30 June 2018. A total of 59 landslide incidences were reported in Kozhikode, Wayanad, Kannur, Malappuram, Palakkad and Idukki districts of Kerala during this spell.

The second spell of heavy rainfall started on 11 July 2018 and continued up to 19 August 2018. The period from 1 to 19 August 2018 was the most severe with high rainfall of $164 \%$ above normal $(758.6 \mathrm{~mm}$ against the normal of $287.6 \mathrm{~mm})^{1}$ and led to devastating landslides in almost all districts of Kerala. During this period, the

*For correspondence. (e-mail: rajesh.geo192@gmail.com) region suffered the worst disaster in its recent history since 1924, with huge loss to life and property. The entire region was struck by excessive rainfall during the late phase of monsoon in August 2018, leading to the filling up of reservoirs, flash floods and several landslides ${ }^{2}$. These landslides, including debris flows, debris slides, subsidence, creep, etc. were reported from 13 out of the total 14 districts of Kerala. Idukki district was the worst affected, where more than 500 landslides were reported to have occurred on revenue land and 1000 landslides within forest areas. More than 250 landslides were reported in Wayanad district, which also included a large number of subsidence or aborted landslides. Kozhikode, Malappuram and Palakkad districts also reported a several landslides, as well as Kannur, Pathanamthitta and Kottayam districts.

Landslide hazard zonation study was conducted in parts of Idukki district along the Thodupuzha-IdukkiMunnar road using geospatial analysis and fragility ranking map $^{3}$. It revealed that out of $438 \mathrm{sq}$. $\mathrm{km}$ of the total study area, about 49.5 sq. km (11\%) fell under highly fragile and fragile zones for landslides.

A total of 6970 landslides were mapped using remote sensing images in three states, namely Kerala, Karnataka and Tamil Nadu, which received excess rainfall in August 2018 (ref. 4). The total numbers of landslides in Kerala was 5191, Idukki district alone witnessed 1632 landslides. Monsoon in Kerala is experienced in two seasons; one from June to September (SW) and the other from October to December (northeast) ${ }^{1}$. Rainfall threshold for Idukki district was established considering 225 landslides that occurred due to rainfall during 2010 to 2018 (ref. 5). According to this study, antecedent rainfall is responsible for the occurrence of landslides in this region rather than daily rainfall ${ }^{5}$. An antecedent rainfall of $70.6 \mathrm{~mm}$ over a period of 10 days and $229 \mathrm{~mm}$ over a period of 40 days can trigger a landslide ${ }^{5}$. According to the Government of Kerala post-disaster needs assessment report, nearly 342 landslides occurred in 10 districts of the state affecting 5.4 million people and causing the loss of 433 human lives ${ }^{2}$.

A total of 14 landslide locations (Table 1) were visited during 12-14 September 2018 just after the disaster and 
Table 1. Location of the 2018 landslides in Kerala, India

\begin{tabular}{|c|c|c|c|}
\hline Location & Latitude & Longitude & Elevation $(\mathrm{m})$ \\
\hline \multicolumn{4}{|l|}{ Puliyanmala-Thodupuzha road-Idukki and Arakkulam villages } \\
\hline Slide 1 & $9^{\circ} 49^{\prime} 35.0^{\prime \prime} \mathrm{N}$ & $76^{\circ} 55^{\prime} 09.7^{\prime \prime} \mathrm{E}$ & 867 \\
\hline Slide 2 & $9^{\circ} 47^{\prime} 35.6^{\prime \prime} \mathrm{N}$ & $76^{\circ} 53^{\prime} 03.3^{\prime \prime} \mathrm{E}$ & 741 \\
\hline Slide 3 & $9^{\circ} 49^{\prime} 35.0^{\prime \prime} \mathrm{N}$ & $76^{\circ} 55^{\prime} 09.7 " \mathrm{E}$ & 806 \\
\hline Perumkala in Idukki village & $9^{\circ} 53^{\prime} 10.5^{\prime \prime} \mathrm{N}$ & $76^{\circ} 56^{\prime} 5.2^{\prime \prime} \mathrm{E}$ & 695 \\
\hline Chittadikavala in Upputhodu village & $9^{\circ} 52^{\prime} 50.0^{\prime \prime} \mathrm{N}$ & $77^{\circ} 00^{\prime} 16.8^{\prime \prime} \mathrm{E}$ & 643 \\
\hline Keerithodu in Kanjikkuzhy village & $9^{\circ} 56^{\prime} 16.1^{\prime \prime} \mathrm{N}$ & $76^{\circ} 57^{\prime} 43.1^{\prime \prime} \mathrm{E}$ & 497 \\
\hline Ponmudy S Valavu in Konnathady village & $9^{\circ} 58^{\prime} 29.6^{\prime \prime} \mathrm{N}$ & $76^{\circ} 02^{\prime} 34.0^{\prime \prime} \mathrm{E}$ & 555 \\
\hline Panniyarkutty in Konnathady village & $9^{\circ} 58^{\prime} 34.7^{\prime \prime} \mathrm{N}$ & $77^{\circ} 03^{\prime} 28.9^{\prime \prime} \mathrm{E}$ & 581 \\
\hline Viswadeepthi School, Adimaly, Mannamkandom village & $10^{\circ} 00^{\prime} 49.3^{\prime \prime} \mathrm{N}$ & $76^{\circ} 56^{\prime} 19.8^{\prime \prime} \mathrm{E}$ & 614 \\
\hline Koompanpara, Mannamkandom village & $10^{\circ} 00^{\prime} 48.5^{\prime \prime} \mathrm{N}$ & $76^{\circ} 57^{\prime} 51.5^{\prime \prime} \mathrm{E}$ & 628 \\
\hline 60th mile, Anaviratty village & $10^{\circ} 01^{\prime} 42.0^{\prime \prime} \mathrm{N}$ & $76^{\circ} 54^{\prime} 15.1^{\prime \prime} \mathrm{E}$ & 855 \\
\hline 2nd mile, Pallivasal village & $10^{\circ} 02^{\prime} 29.1^{\prime \prime} \mathrm{N}$ & $77^{\circ} 02^{\prime} 17.2^{\prime \prime} \mathrm{E}$ & 1179 \\
\hline Arts College, Munnar & $10^{\circ} 04^{\prime} 57.4^{\prime \prime} \mathrm{N}$ & $77^{\circ} 04^{\prime} 22.5^{\prime \prime} \mathrm{E}$ & 1540 \\
\hline Devikulam near Public Health Center (PHC) at Kannan Devan Hills (KDH) & $10^{\circ} 04^{\prime} 02.4^{\prime \prime} \mathrm{N}$ & $77^{\circ} 06^{\prime} 35.2^{\prime \prime} \mathrm{E}$ & 1629 \\
\hline
\end{tabular}

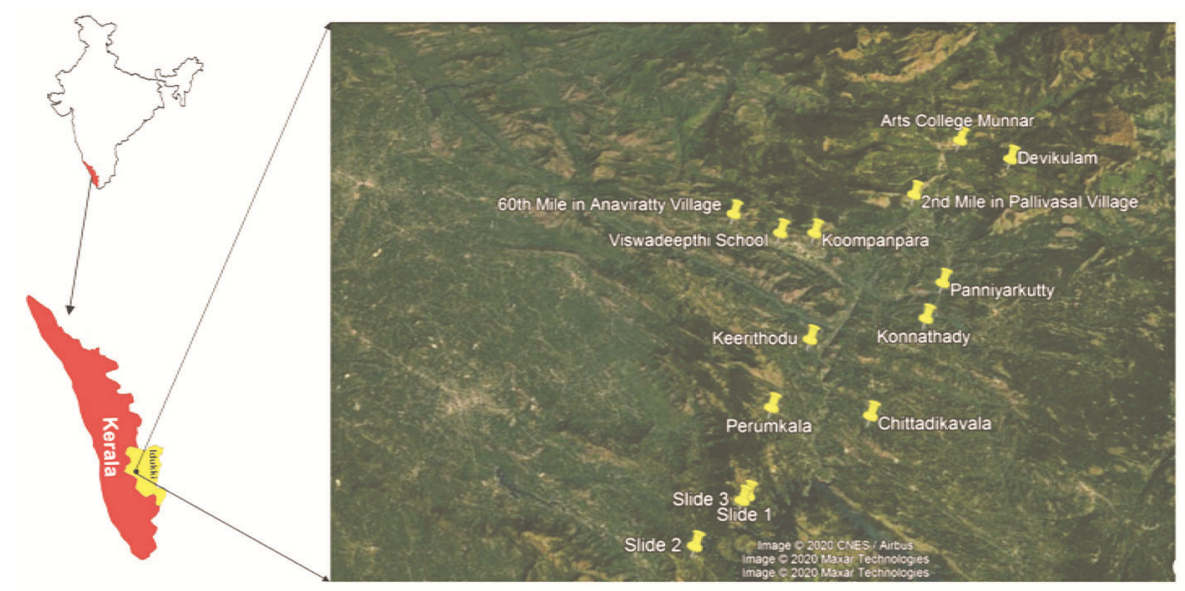

Figure 1. Map of the study area showing landslide locations in Kerala, India.

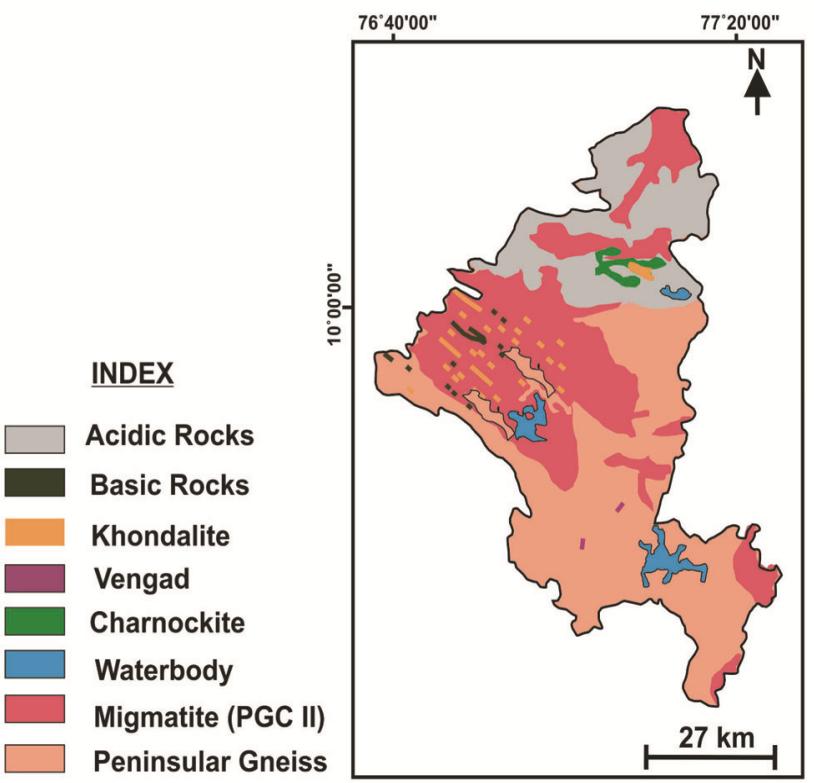

Figure 2. Geological Map of Idukki district, Kerala. field observations were made (Figure 1). The objective of the study was to carry out a preliminary assessment of the landslides to understand their mechanism in the lithotectonic set-up of the Western Ghats and the causative factors for triggering such events. Based on these observations, we report a few lessons that can be considered in future initiatives for landslide disaster risk reduction during the reconstruction phase of the affected areas.

\section{Geology of Idukki district}

Idukki district is the second largest district, in terms of area, in the southcentral part of Kerala, where more than half of the area is covered by forest ${ }^{5}$. It is one of the landslide-prone areas in the Western Ghats ${ }^{6,7}$ and one among the 13 districts which were affected by the August 2018 floods and landslides. Geologically, the area forms a part of the Precambrian metamorphic shield of South India comprising rocks of the Wayanad, Khondalite, Charnockite and Migmatite Groups ${ }^{8}$. Major rock units of 

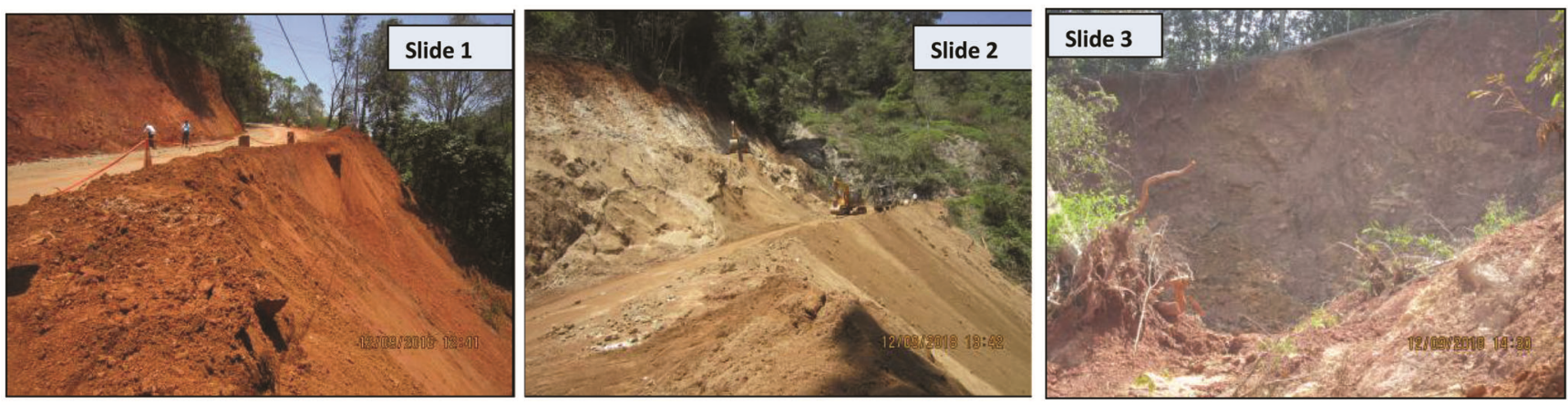

Figure 3. Landslides at Puliyanmala-Thodupuzha Road-Idukki and Arakkulam villages.

the area are garnet biotite gneiss, hornblende biotite gneiss, pink granite gneiss and a small patch of charnockite body ${ }^{8}$. A major part of the district falls in the hill ranges of the Western Ghats, except for Thodupuzha block and the western part of Elamdesam block which fall in the midland region of the state. Geologically, the district can be divided into three major belts in the northsouth direction: (i) Peninsular Gneissic Complex in the north; (ii) Charnockite Group of rocks in the south, and (iii) the Migmatitic Complex between them. Figure 2 shows the geological map of Idukki district.

\section{Field observations on landslides in Idukki district}

\section{Landslides along Puliyanmala-Thodupuzha road of Idukki and Arakkulam villages}

Three landslides were visited around Idukki and Arakkulam villages along Puliyanmala-Thodupuzha road in the Idukki reserve forest area.

Slide 1: This landslide occurred below road level with collapse of the road which was unsupported (Figure 3 ). Thick cover of lateritic red soil was observed at the site. Above road level, the slope was moderate $\left(30^{\circ}-40^{\circ}\right)$ and straight in nature with terrace cultivation. Tension cracks and depression pits on the uphill slope above road level were observed. The possible causes for this landslide were: (i) toe-cutting during heavy water flow due to highintensity rainfall by a perennial stream flowing at the base of the slope below the road level, and (ii) development of high water pressure in the lateritic soil with more clay content (sticky in nature and more water-retention capacity in comparison to water-draining capacity). It was also observed at the site that back-cutting of the road to maintain its width was being done after the occurrence of the landslide. However, the cut slope was left almost vertical without any retaining structure. The slope though, not too high, needs to be protected by proper retaining wall (gabion wall) with provision of catch water drain at the road level to discharge the surface water properly to the nearby culvert. Retaining structures just below the road level and also at the stream level to avoid further toe-cutting need to be provided.

Slide 2: This was a translational debris slide of the overburden material on the foliation plane of the highly weathered biotite gneiss (Figure 3). The road collapsed and was washed away with the debris slide. As informed, it is an old debris-flow area along a natural stream during every monsoon season. It was observed to be a waterlogged area, as water was oozing out of in situ rock strata at many places (Figure 3). The possible cause may be due to the fact that the old debris slide/flow area was left unprotected at the road level as well as below it. Heavy water seepage had caused high-grade weathering to in situ rocks (biotite gneiss). Dip-slope relationship of the foliation plane facilitated translational (planar) mode of failure of the overlying debris and weathered rock mass. Back-cutting of the road to maintain its width was being done after the landslide. The in situ rocks are exposed due to excavation. It is proposed to protect the base of this cut-slope with a retaining wall and the exposed rock slope face with properly anchored wire-mesh to protect rockfall (fractured rock mass). Drainage measures along the existing natural stream along with properly designed culvert and catch-water drain at the road level need to be provided. The accumulated debris on the road dumped on the valley side needs to be protected with proper vegetation growth.

Slide 3: In this case, circular failure of overburden debris and highly weathered rock material had occurred (Figure 3). Foliation plane of biotite gneiss is in dip-slope relationship facilitating further sliding. Foliation plane along the slip surface has been exposed at the failure site (Figure 3). As in the case of slide 1, the lateritic soil with more clay content has much more water-retention capacity in comparison to water-draining capacity, and thereby high water pressure built-up within the slope material caused the failure. Therefore, it can be proposed to protect the base of this cut-slope with a retaining wall and the exposed rock slope face with properly anchored wire 


\section{RESEARCH ARTICLES}

mesh to protect the rock slide and rockfall (fractured rock mass). The accumulated debris on the road dumped on the valley side needs to be protected with proper vegetation growth. Catch water drain at the road level has to be provided to channelize the surface water to the drainage culvert.

\section{Landslide at Perumkala in Idukki village}

A huge debris slide occurred at the crown of the slope on 15 August 2018 (Figure 4). A motorable road existing at the middle level of the slope and few houses on the slope below the road level were washed away with the slided debris material to the riverbed level (Figure 4). A huge accumulation of debris had occurred at the middle portion of the slope at the road level. The in situ rock of biotite gneiss was exposed at the crown in the zone of initiation of the debris slide showing inward dipping of the foliation plane. The possible causes for the occurrence of this slide may be attributed to huge debris cover on highly weathered strata on the slope, high-intensity rainfall triggering the process to the already saturated slope material and lack of earlier protection to the road cut-slope. Remedial measures in terms of retaining structures at the base of the slope at road level and at the riverbed level are to be properly designed and implemented. The residents still living in a building at the riverbed level should be evacuated immediately and rehabilitated.

\section{Landslide at Chittadikavala in Upputhodu village}

A huge debris slide occurred on the side hill slope of a natural perennial stream on 17 August 2018 night (9:30 pm; Figure 5). As informed by local villagers and as observed at the site, the slide had occurred in three stages. A huge boulder got dislodged initially along the stream with huge water flow due to heavy rainfall during this period. The rolling of this huge boulder eroded soil mass from the toe of the slope with an initial debris slide. Subsequently, the soil overburden at the crown of the slope slided down due to removal of toe support. A huge amount of debris along with large boulders were transported along the stream flow and damaged the road, agricultural land and houses (one above and one below road level) around the affected area on both uphill and downhill sides of the road. At the zone of initiation of the slide, the gneissic rocks got exposed with foliation planes having dip-slope relationship. A huge accumulation of debris material, huge boulders and sand bed $>1 \mathrm{~m}$ thick were observed above road level. The sand and clay are found as by-products of the highly weathered biotite gneiss. The sand got deposited in the form of a sand bed in the process of transportation by water. The clay got mixed with water and was transported to a farther distance down slope. The possible causes for this slide can be listed as: (i) huge debris cover on highly weathered strata on the slope; (ii) high-intensity rainfall which triggered the dislodging of a huge boulder that eroded the toe of the debris slide on its path of rolling down stream, and (iii) no pre-existing protection measures for the road cutslope. Proper remedial measures in terms of retaining structures need to be provided at the base of the slope and at the road level, both on the uphill and downhill sides. Removal of accumulated debris, sand and boulders on the drainage path above road level and using them in remedial and reconstruction works at this particular site are suggested. This will solve the problem of unloading the crown portion of the slope to control further sliding. A natural drainage path has to be made lined all along up to the valley side with provision for properly designed culvert at the road level according to the discharge capacity of the drain. Also a catch water drain at the road level can help channelize the surface water to the valley side.

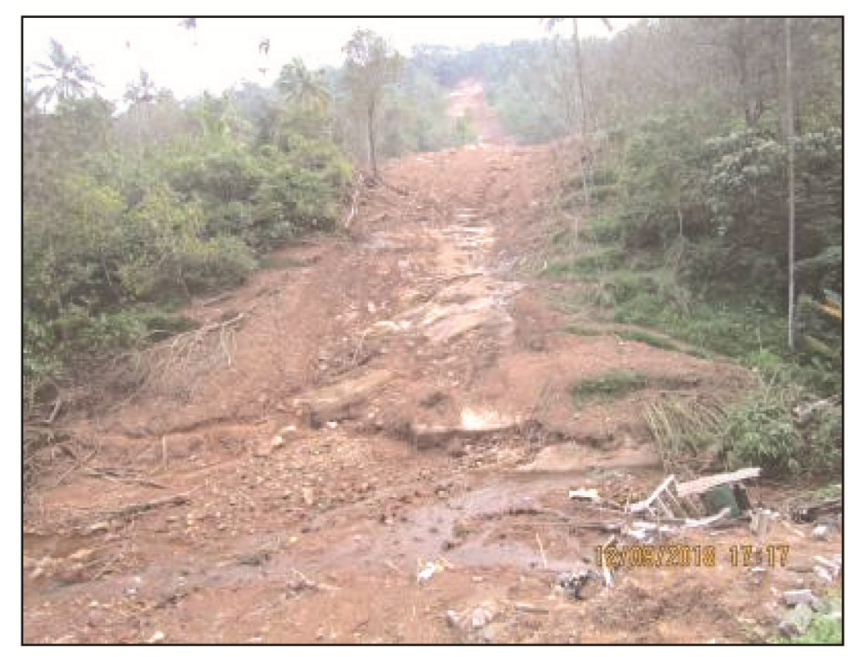

Figure 4. Landslide at Perumkala in Idukki Village.

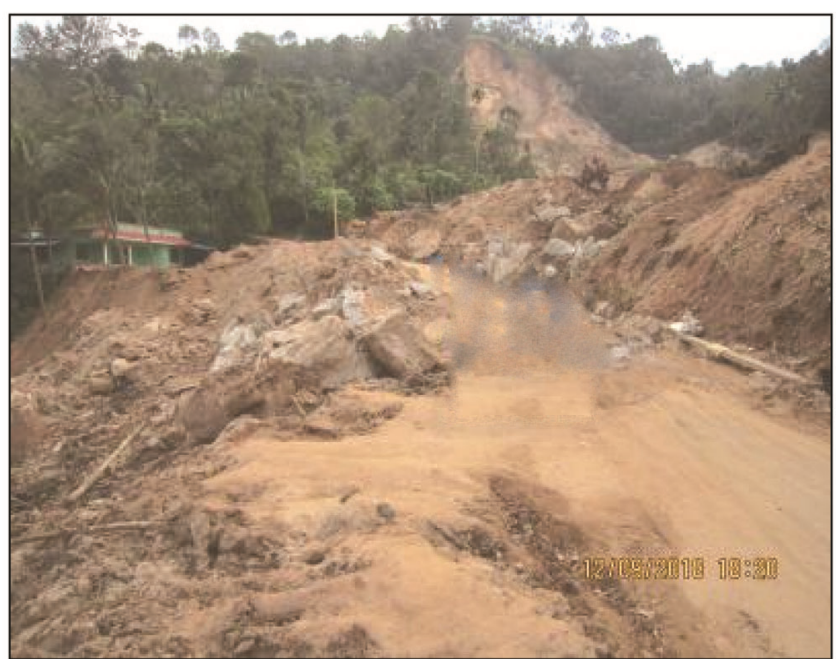

Figure 5. Landslide at Chittadikavala in Upputhodu Village.

CURRENT SCIENCE, VOL. 119, NO. 11, 10 DECEMBER 2020 


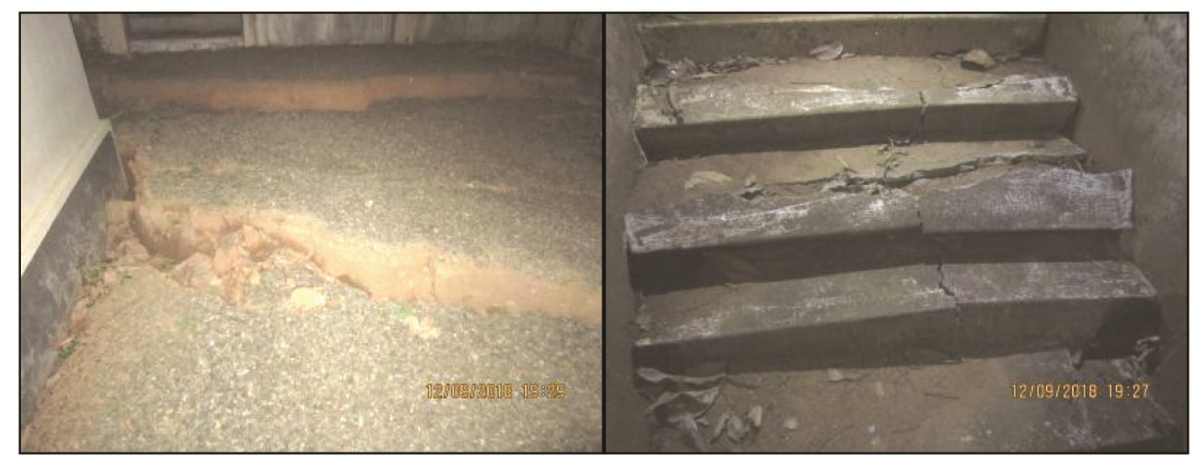

Figure 6. Damages in houses and surroundings due to landslide at Keerithodu in Kanjikkuzhy village.

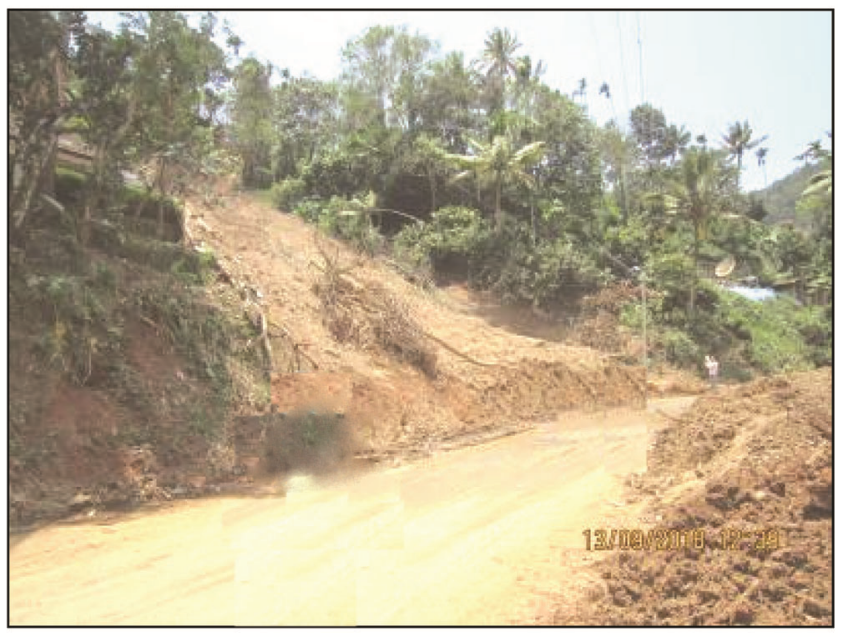

Figure 7. Landslide at Ponmudy S Valavu in Konnathady village.

\section{Landslide at Keerithodu in Kanjikkuzhy village}

This is an area shattered with slump failure by the development of numerous wide-open, long cracks all around. A lined flowing drain exists at the base of the slope. The ground around one existing reinforced cement concrete (RCC) building at the lower level of the slope and building itself have developed many wide-open cracks. The approach road and staircase to this building also show cracks, distress and damage (Figure 6). On one side of the building there is detachment of foundation from the ground and differential settlement to this portion of the building is also observed (Figure 6). A motorable road at a higher elevation of the slope has also developed cracks. Approximately 50 houses around this motorable road have experienced minor or no distress as of the time of site visit. However, there exists a greater risk to these houses due to subsidence and cracks as observed around the slope. Radial circular tension cracks all around the slope show creep and slump movements in the whole slope. Possible causes for this failure could be the following: (i) highly saturated slope with no proper drainage measures; (ii) loading of the slope with many buildings on cut- and fill-ground with absolutely no protection measures at the uphill and downhill sides, and (iii) no protection at the toe of the slope as well as at the road level. Proper remedial measures in terms of retaining structures at the base of the slope, at the road level on both the uphill and downhill sides and at cut-slopes around the buildings need to be implemented. Suitable surface drainage measures also need to be planned for the whole slope. Crack-filling using local soil material with proper compaction and sealing with bentonite clay layer on the surface after filling are to be adopted. This site has to be taken on high-priority basis to protect rest of the 50 houses at higher elevation from damage.

\section{Landslide at Ponmudy S Valavu in Konnathady village}

This was a huge translational debris slide along the foliation plane at the zone of initiation. The debris flowed along the natural stream to the river valley and damaged houses on the slope as well as causing loss of lives (Figure 7). As observed, the slope comprised of huge soil/debris overburden on highly weathered gneissic rocks. After sliding, fresh gneissic rocks with the foliation plane having dip-slope relationship were exposed at the road level. The debris material comprised of finer materials like silt and clay that were lateritic in nature. A huge quantity of sand has been deposited in the area, which seems to be a product of highly weathered, coarsegrained biotite gneiss. Continuous water seepage along the foliation planes was observed at the site. Possible causes for this failure could be: (i) huge quantity of debris overburden on highly weathered gneissic rocks on the unprotected slope at the base at road level; (ii) highly saturated slope with no proper drainage measures; (iii) dip-slope relationship of foliation plane facilitating the translational debris slide charged with heavy water pressure, and (iv) high intensity rainfall triggering the sliding phenomenon. Proper remedial measures in terms of 


\section{RESEARCH ARTICLES}

retaining structures at the base of the slope at road level on both uphill and downhill sides need to be implemented. The exposed soil slope at the crown portion should be treated with soil nailing along with other bioengineering measures to protect further soil erosion and sliding. Suitable drainage measures are to be planned for the whole slope. Local sand, soil and boulders should be used for reconstruction of the area.

\section{Landslide at Panniyarkutty in Konnathady village}

A huge debris slide (circular failure) damaged the nearby shopping complex and houses. It moved further downhill and blocked the river channel forming a dam (Figure 8). The heavy water flow in the river channel due to water release from Ponmudy reservoir changed its course to the other side of the valley and washed away shops and houses on the opposite riverbank (Figure 8). Being identified as a potential landslide zone during heavy rainfall, the people were shifted to camps prior to the incidence; thereby avoiding loss of life. In this case, a huge quantity of debris overburden on highly weathered gneissic rocks was lying on the unprotected slope. The slope got highly saturated with monsoon precipitation and was devoid of proper drainage measures. High-intensity rainfall triggered the sliding phenomenon. Proper remedial measures in terms of retaining structures at the base of the slope at the road level on both the uphill and downhill sides need to implemented. The exposed soil slope at the crown portion should be treated with soil nailing along with other bioengineering measures to protect further soil erosion and sliding. Suitable drainage measures need to be planned for the whole slope. Local sand, soil and boulders should be used for reconstruction of the area.

\section{Creep movement in the agricultural land near Viswadeepthi School, Adimaly, Mannamkandom village}

This is an old creeping slope as witnessed by bent trees all around the agricultural land. The creep movement got triggered with high-intensity rainfall and developed huge, wide-open, radial and circular cracks all around the land at different levels from the toe up to the crown (Figure 9). Three houses at the toe of this huge agricultural land (5 acres) showed high intensity of distress in the form of ground cracks, structural damage to the building, etc. (Figure 9). The damaged houses should be abandoned and no one should be allowed to live in any part of this agricultural land. Crack-filling using local soil material with proper compaction and sealing with bentonite clay layer on the surface after filling need to be adopted. As this is an agricultural land without any habitation, the area with creep movement will be naturally stabilized with time. Vegetation growth in the form of trees and shrubs with their roots creating an interlocking network can strengthen and stabilize the unconsolidated material naturally with time. Hence, this does not require any investment on remedial measures. However, buildings in the vicinity need to be strengthened with structural measures and slope protection walls, or the resettlement of these houses in the near vicinity of the creeping slope is recommended.

\section{Landslide at Koompanpara in Mannamkandom village}

Debris slide and flow along an existing natural drainage had occurred here (Figure 10). In situ less-weathered gneissic rocks with sidewise gently dipping foliation plane got exposed after the sliding (Figure 10). Debris slide on the side slope blocked the path of the natural stream, and subsequent change in the flow path of the stream carrying debris damaged one of the buildings on the roadside slope causing loss of life and injury to the inhabitants (Figure 10). Though the retaining wall below the road level and culvert for natural drainage at the road level pre-existed, the road-cut slope was left unprotected. Buildings and the approach road have been constructed over unconsolidated debris overburden. Loading of the unprotected road-cut-slopes with buildings and human intervention in the natural drainage system is the primary cause for this sliding phenomenon. Retaining structure to the unprotected road-cut-slope with proper drainage alignment to the natural drainage to discharge water to the culvert needs to be provided. The exposed soil slope face after sliding should be treated with soil nailing with provision for suitable geo-grids and vegetation growth. Existing buildings at the crown of the slide area should be vacated and the residents should be relocated.

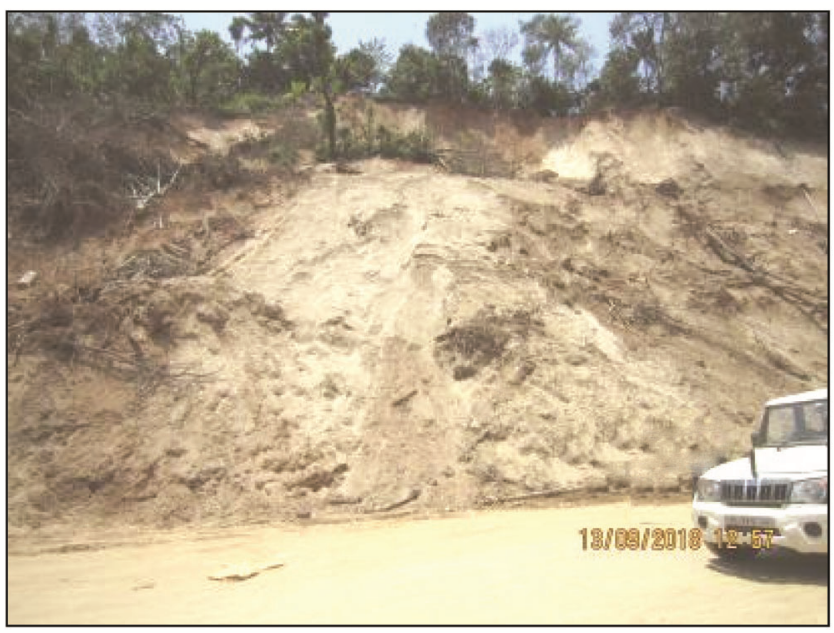

Figure 8. Landslide at Panniyarkutty in Konnathady village. 


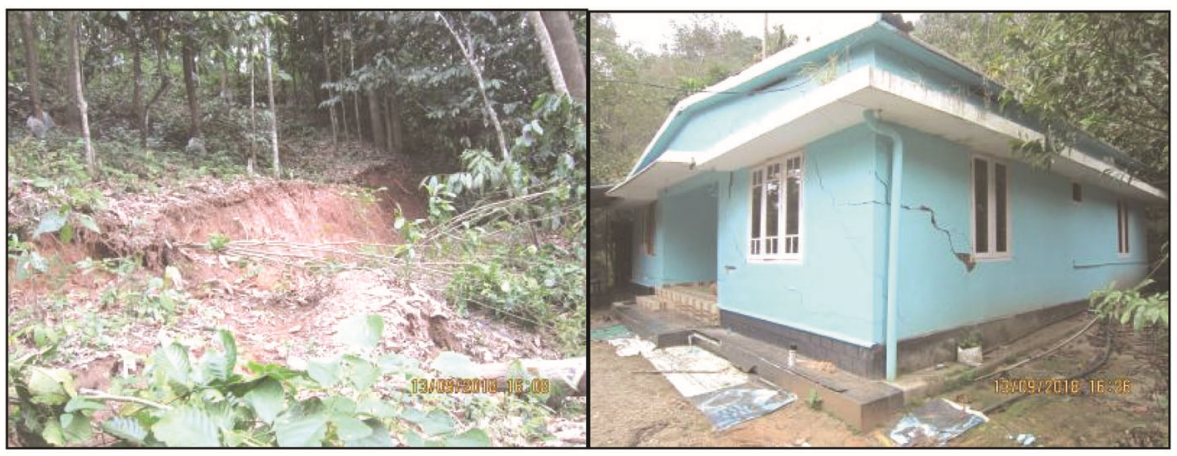

Figure 9. Creep movement in the agricultural land near Viswadeepthi School, Adimaly, Mannamkandom village.

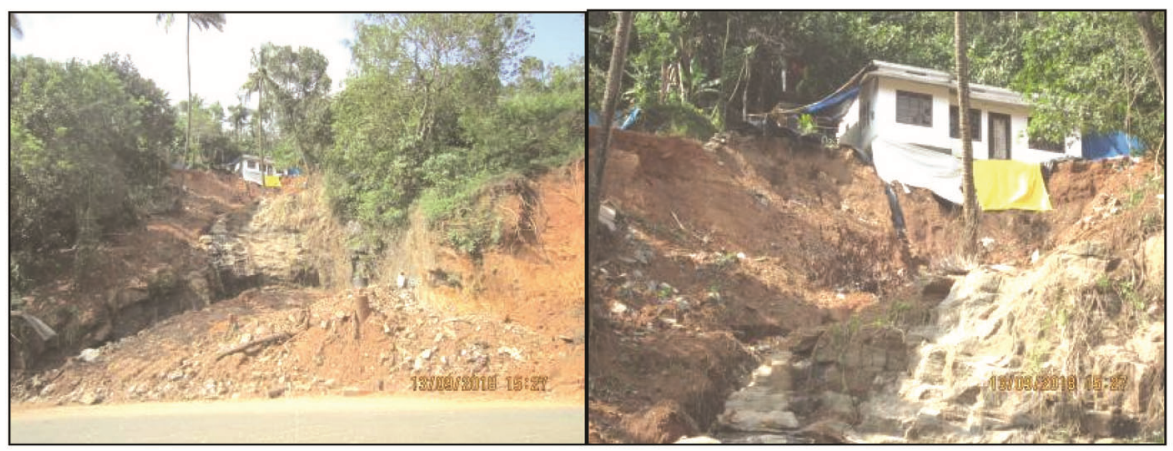

Figure 10. Landslide at Koompanpara, Mannamkandom village.

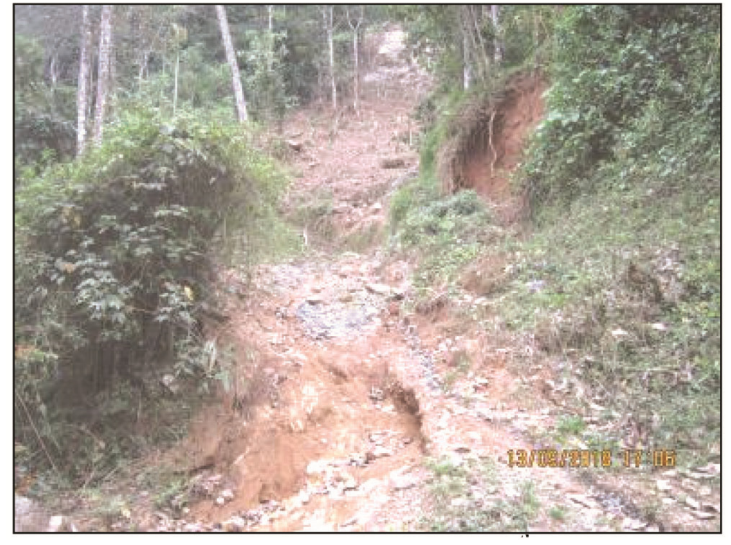

Figure 11. Debris slide damagingagricultural land at 60th mile in Anaviratty Village.

\section{Debris slide damaging agricultural land at 60th mile in Anaviratty village}

A minor debris slide had occurred with water flowing from higher elevations during heavy rainfall (Figure 11). The topsoil and debris overburden has slided down damaging the agricultural land above road level without affecting the road (Figure 11). The in situ rocks have been exposed after the sliding phenomenon. Dry stone masonry retaining wall exists at the roadside in this location. No remedial measure is required as the debris overburden has already slid exposing the bedrock.

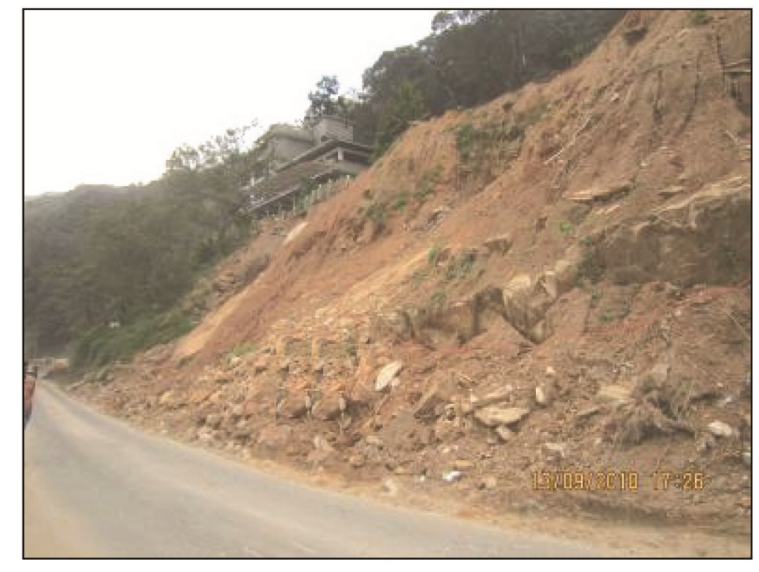

Figure 12. Landslide at 2 nd mile in Pallivasal Village.

\section{Landslide at 2nd mile in Pallivasal village}

A huge debris slide above road level occurred affecting the tea gardens below and part of a huge resort above the slid area (Figure 12). The in situ fine-grained hornblendebiotite gneiss with inward dipping foliation plane and two sets of joints was overlain by a huge quantity of debris overburden. The road-cut-slope was left unprotected (Figure 12). Huge multistoried resorts have been allowed to be built on the huge debris cover by cut-and-fill method above the unprotected road-cut-slope (Figure 12). High-intensity prolonged rainfall triggered the saturated 


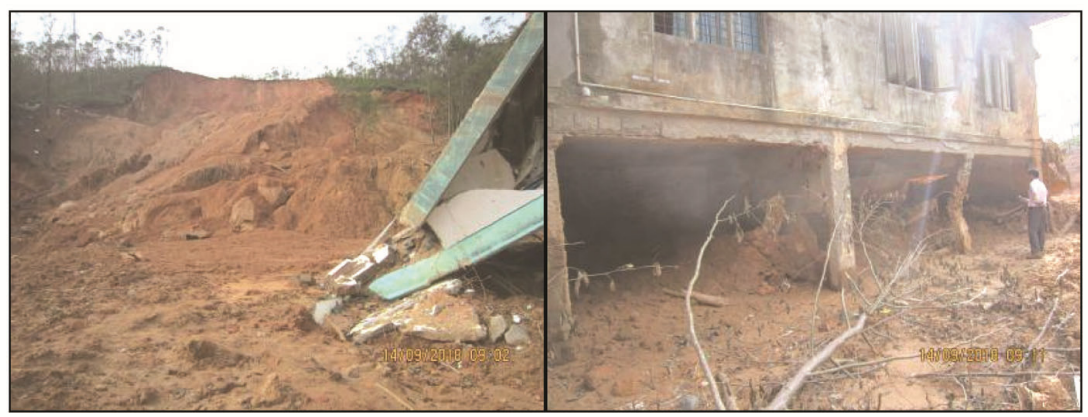

Figure 13. Landslide at Arts College Munnar.

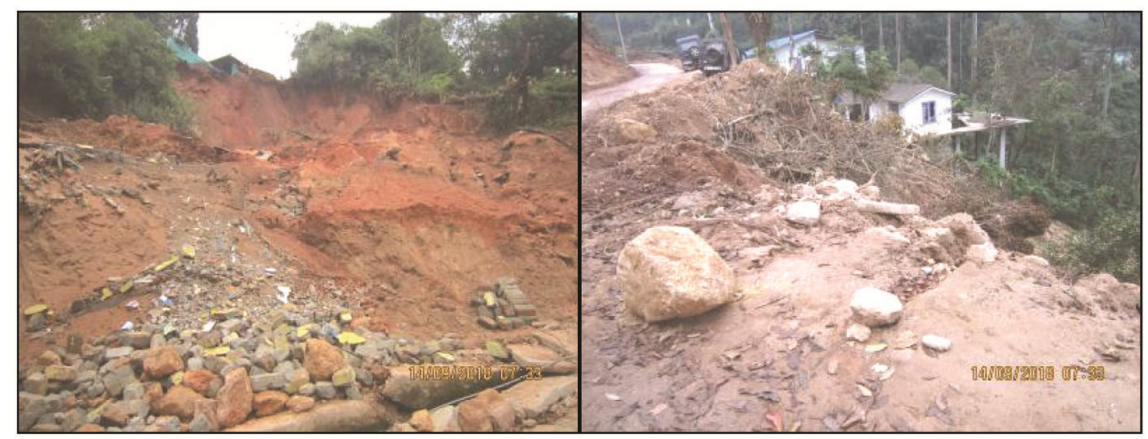

Figure 14. Landslide at Devikulam near Public Health Center (PHC) at Kannan Devan Hills (KDH).

debris overburden to slide. Heavy loading of the unprotected road-cut-slopes with buildings destabilized the saturated debris slope. Properly designed retaining structure with actual loading considerations to the unprotected road-cut-slope along with proper drainage measures need to be provided. The exposed soil slope face after sliding should be modified with proper terracing and then treated with soil nailing. Implementation of suitable geo-grids with provision of vegetation growth on the slope face is also suggested.

\section{Landslide at Arts College, Munnar}

Huge debris slide and flow occurred on 15 August 2018 night in the campus of Government Arts College, Munnar (Figure 13) totally damaging the newly constructed and unoccupied Boys' hostel building and partly damaging the classroom building. The administrative building was also affected by a debris slide behind it. The debris slide occurred at the crown of the slope and lateritic red soil flowed with water along the existing natural drain at the right flank of the landslide as mudflow. The mudflow also affected the highway below the college campus and found its way to the river down below. As informed, the college campus had experienced landslides in the past during 2005. It is an old and potential landslide area, which got reactivated this year due to high-intensity prolonged rainfall. Prior to the landslide during 15 August 2018, the District Hazard Analyst had surveyed the area in June 2018 and reported development of dis- tress and cracks around this area. The area is covered by huge debris/soil overburden and is underlain by highly weathered, disintegrated, gneissic rock with outwardly dipping foliation plane. There have been several construction activities to build multistoried structures in the college campus in the recent past by the Public Works Department. No protection measure was witnessed on cut-slopes in the campus as well as on roadside. The triggering phenomenon of this failure may be attributed to reactivation of the potential old landslide zone with highintensity prolonged precipitation. The primary cause of the slide is the overloading of unprotected hill slope with huge construction of multistoried buildings over debris overburden. No drainage measure was also provided to channelize the surface water and to prevent the slope from heavy water seepage. This landslide being a huge and active phenomenon needs to be studied in detail to prepare a detailed project report (DPR) for its mitigation. Only then can scientifically designed integrated control measures be implemented to achieve stability.

\section{Landslide at Devikulam near PHC at Kannan Devan Hills}

This is a debris slide-cum-mudflow down the slope (Figure 14). There was presence of huge debris cover comprising lateritic red soil and boulders on the highly weathered gneissic rocks above the unprotected road-cutslope. The debris slide flowed downstream with rainwater as a mudflow, damaging three houses at above and below 


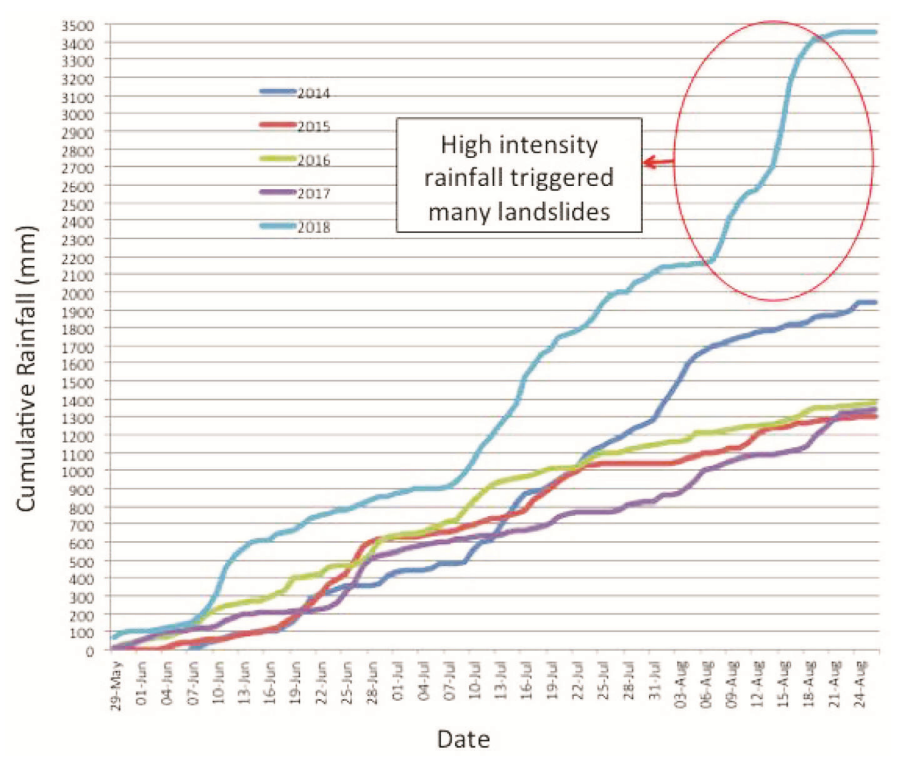

Figure 15. Cumulative rainfall during SW monsoon period (29 May to 26 August) of last 5 years (2014-2018) in Idukki District (Source: Taluk rain gauges).

road level, with the loss of two lives. Human habitation exists all around this area. The Devikulam colony is located on the further downhill side of the landslide (Figure 14). The possible causes of this failure may be attributed to high-intensity prolonged rainfall triggering the saturated huge debris overburden to slide, unprotected road-cut-slope and lack of proper drainage measures along the road and around the inhabited area. The suggestive remedial measures for stability of this area are as follows: (i) retaining structure at the road level for providing toe support to the slope, and (ii) catch water drain at the road level and around the inhabited area to channelize surface water to the valley side.

\section{Observations and lessons learnt}

\section{General observations on causative factors for the occurrence of landslides and loss of life and property in Idukki district}

Based on the post-disaster field visits to major landslideaffected areas of Idukki district, the following general observations on their failure mechanism and causative factors could be made:

- The area comprises high-grade metamorphic rocks (biotite gneiss and hornblende-biotite gneiss), which are prone to weathering. A very high-grade weathering has been witnessed in these rocks near the surface with a gradational effect below, as observed on cutslopes.

- The area is covered with a thick overburden material (comprising mainly of lateritic red soil and boulders) underlain by highly weathered gneissic rocks that geotechnically behave like a soil.

- Lateritic soil with more clay content (sticky in nature) has much more water-retention capacity in comparison to water-draining capacity; thereby developing high water pressure inside the slope material.

- Dip-slope relationship of foliation plane of gneissic rocks facilitates translational (planar) mode of failure of the overlying debris and weathered rocks.

- Toe-cutting by the perennial stream flowing at the base of the slope during heavy water flow due to highintensity prolonged rainfall.

- High-intensity rainfall during August 2018 triggered landslides on the already saturated slope material (Figure 15).

- No protection to the road-cut-slopes was observed as a general practice in these hilly areas.

- Human intervention with the natural drainage system.

- No provision of catch water drains alongside the road to channelize surface water to the culverts.

- Ill-designed culverts which do not cater to the heavy water flow capacity of the drains.

- Heavy loading of the slope with buildings/multistoried resorts on cut-and-fill ground with absolutely no protection measures at the uphill and downhill sides.

- Landslide damming at riverbed forced the river to change its course to the other side of the valley.

- Reactivation of the potential old landslide zone.

\section{General recommendations for mitigation and reconstruction of landslide-affected areas}

The following recommendations are given based on the observations made during field visits to many 


\section{RESEARCH ARTICLES}

landslide-affected areas and lessons learnt thereby in Idukki district:

- Filling of cracks by local soil material with proper compaction and sealing with local clay/bentonite clay slurry on the crack surfaces.

- Use of slid/transported and deposited sand, debris and stones on the hillsides and riverbed respectively, in the reconstruction work of landslide mitigation and other works.

- Road-cut-slopes and slopes around buildings or any other infrastructure should be protected with retaining and other appropriate structures to provide toe support and avoid landslides.

- Culverts on roads must be designed with discharge capacity in accordance with the water flow in the catchment area.

- Catch water drains alongside the road and in the inhabited areas to channelize the surface water to the culverts or natural streams must be properly provided.

- Encroachment in the riverbed or flood inundated areas must be prohibited.

- Bridge piers and riverbanks near the bridges must be protected from erosion with proper retaining structures.

- Human settlements below or above, or in the influence zone of the old or active landslide areas must be restricted. Such existing settlements must be shifted to safer locations.

- Permission for the construction of buildings/resorts in the hills should be provided after a judicious study of the hill slopes from instability point of view and proper review of the DPR.

- Identified high-risk and high-priority areas in terms of safety to the vital infrastructures and installations (such as highways, buildings, hydroelectric power houses, bridges, schools/colleges, etc.) against landslides must be studied in detail to prepare a DPR prior to implementation of landslide mitigation measures.

- Training of engineers from the state Government Departments such as PWD, Roads, Buildings and Highways who are engaged in infrastructure developments involving landslide mitigation and slope protection works must be done to prepare DPRs.

\section{Conclusion}

The landslides that occurred in August 2018 in Kerala were one of the most devastating events after the 2013 Kedarnath tragedy in the last decade. The primary triggering factor for initiation of such landslides is high intensity prolonged precipitation. However, the major causative factors as observed from site visits are listed in this study. Idukki district was the worst affected by floods and landslides. In earlier studies, Idukki was demarcated as an area prone to landslides. Apart from the natural causes (i.e. high intensity prolonged rainfall, existing litho-tectonic set-up of the area, slope geometry, etc.) over which humans have no control, lack of scientific interventions for sustainable developmental activities was the major reason behind such landslide disasters causing loss of life and property in Idukki District. For example, no protection to the road-cut-slopes was observed as a general practice in this hilly area. Human intervention with the natural drainage system blocks the natural flow of water by creating pore water pressure in the surrounding soil mass. There was heavy loading of the slope with buildings/multistoried resorts on cut-and-fill-ground with absolutely no protection measures at the uphill and downhill sides. Therefore, special training should be given to the engineers of the state government departments regarding disaster mitigation and risk reduction.

1. Viswanadhapalli, Y., Srinivas, C. V., Basha, G., Dasari, H. P., Langodan, S., Ratnam, M. V. and Hoteit, I., A diagnostic study of extreme precipitation over Kerala during August 2018. Atmos. Sci. Lett., 2019, 20(12), 941-950.

2. Kerala post disaster needs assessment floods and landslides August 2018. Government of Kerala, Thiruvananthapuram, 2018, pp. $1-440$.

3. Abraham, P. B. and Shaji, E., Landslide hazard zonation in and around Thodupuzha-Idukki-Munnar road, Idukki district, Kerala: a geospatial approach. J. Geol. Soc. India, 2013, 82(6), 649-656.

4. Martha, T. R., Roy, P., Khanna, K., Mrinalni, K. and Kumar, K. V., Landslides mapped using satellite data in the Western Ghats of India after excess rainfall during August 2018. Curr. Sci., 2019, 117(5), $804-812$.

5. Abraham, M. T., Pothuraju, D. and Satyam, N., Rainfall thresholds for prediction of landslides in Idukki, India: an empirical approach. Water, 2019, 11(10), 2113.

6. Kuriakose, S. L., Sankar, G. and Muraleedharan, C., History of landslide susceptibility and a chorology of landslide-prone areas in the Western Ghats of Kerala, India. Environ. Geol., 2009, 57, 15531568.

7. Sajinkumar, K. S., Asokakumar, M. R., Sajeev, R. and Venkatraman, N. V., A potential headward retreat landslide site at Munnar, Kerala. J. Geol. Soc. India, 2017, 89(2), 183-191.

8. Sulal, N. L. and Archana, K. G., Note on post disaster studies for landslides occurred in June 2018 at Idukki District, Kerala. Geological Survey of India, Thiruvananthapuram, 2019.

ACKNOWLEDGEMENT. We thank the Director, CSIR-Central Building Research Institute, Roorkee for permission to publish this paper.

Received 6 January 2020; revised accepted 19 June 2020

doi: $10.18520 / \mathrm{cs} / \mathrm{v} 119 / \mathrm{i} 11 / 1797-1806$ 